\section{Review}

Correspondence

Petra C. F. Oyston

pcoyston@dstl.gov.uk

\title{
Francisella tularensis: unravelling the secrets of an intracellular pathogen
}

\author{
Petra C. F. Oyston \\ Biomedical Sciences, DSTL Porton Down, Salisbury, Wiltshire SP4 OJQ, UK
}

\begin{abstract}
Francisella tularensis has been recognized as the causative agent of tularaemia for almost a century. Since its discovery in 1911, it has been shown to infect a wide range of hosts, including humans. As early as the 1920s it was suggested to be an intracellular pathogen, but it has proven to be an enigmatic organism, whose interaction with the host has been difficult to elucidate, and we still have a very limited understanding of the molecular mechanisms of virulence. However, the recent availability of genome sequence data and molecular tools has allowed us to start to understand the molecular basis of $F$. tularensis pathogenicity, and will facilitate the development of a vaccine to protect against infection.
\end{abstract}

\section{Francisella tularensis}

Francisella tularensis is a small pleiomorphic Gramnegative coccobacillus. It was first isolated in 1911 from ground squirrels found dying of a plague-like illness in Tulare County, CA, USA (McCoy \& Chapin, 1912). Initially called Bacterium tularense, it was eventually allocated to a new genus named Francisella in honour of the man who pioneered research on the organism, Dr Edward Francis (Dorofe'ev, 1947). Modern taxonomic methods have assigned Francisella to the $\gamma$-subclass of Proteobacteria (Forsman et al., 1994). Sequencing of $16 \mathrm{~S}$ genes, and more recently whole genome analysis, indicates that the closest relatives are endosymbionts, such as Wolbacchia persica (Forsman et al., 1994; Keim et al., 2007). The taxonomic status of Francisella is supported by an unusual fatty acid composition and the high lipid content of the cell wall (Hood, 1977). Three species are currently recognized: F. tularensis, Francisella philomiragia and Francisella novicida, although it has been suggested that $F$. novicida should be reclassified as a subspecies of $F$. tularensis, and this classification has been adopted in many publications, including Bergey's Manual of Systemic Bacteriology (Sjostedt, 2005). Three F. tularensis subspecies are recognized, tularensis, holarctica and mediasiatica, which differ in geographical distribution and virulence (Table 1). The subspecies tularensis has been divided into two clades, A.I and A.II (Farlow et al., 2005; Johansson et al., 2004), based on geographical distribution, disease outcome and transmission routes. However, recent isolation of Francisella-like organisms from fish and human infections indicates that the genus may be more diverse and widespread than previously assumed (Nylund et al., 2006; Ostland et al., 2006; Whipp et al., 2003).

$F$. tularensis is a fastidious organism that requires enriched medium for growth, such as cysteine glucose blood agar or an enriched cysteine-supplemented chocolate agar (Ellis et al., 2002). A heavy inoculum will yield visible growth in $18 \mathrm{~h}$ at $37^{\circ} \mathrm{C}$, but the appearance of individual colonies may require 2 to 4 days of incubation. On chocolate agar, colonies are 2 to $4 \mathrm{~mm}$ in size, greenish-white, round, smooth and slightly mucoid, whilst on media containing whole blood there is usually a small zone of $\alpha$-haemolysis surrounding colonies. F. tularensis does not grow well in liquid medium even when the medium is supplemented with cysteine. Fully virulent strains of $F$. tularensis must be handled at containment level 3 (Titball et al., 2007). In the USA, F. tularensis is listed as a 'select agent' by the Centers for Disease Control and Prevention.

\section{Tularaemia}

Tularaemia is a zoonotic infection caused by $F$. tularensis (Ellis et al., 2002; Sjostedt, 2007). It circulates in populations of rodents and lagomorphs, and outbreaks in humans often parallel outbreaks in animal populations. However, it is not clear whether these animal species are the true reservoir of the bacterium in the environment. A wide range of arthropod vectors have been implicated in the transmission of the pathogen causing tularaemia between mammalian hosts, including mosquitoes, ticks and deer flies (Boyce, 1975; Mörner, 1992). These vectors can also transmit the pathogen to man. In addition, F. tularensis can be acquired by contact with, or ingestion of, contaminated material, including food and water, and by inhalation of infectious particles. Rural populations, and especially those individuals who spend periods of time in endemic areas, such as farmers, hunters, walkers and forest workers, are most at risk of contracting tularaemia (Levesque et al., 1995; Syrjala et al., 1985). Outbreaks associated with contaminated water supplies can involve large numbers of cases, but usually the incidence of the 
Table 1. Virulence and distribution of Francisella

\begin{tabular}{|c|c|c|c|c|}
\hline \multirow{2}{*}{$\begin{array}{l}\text { Francisella } \\
\text { species }\end{array}$} & \multirow[t]{2}{*}{ Subspecies } & \multirow[t]{2}{*}{ Relative virulence } & \multicolumn{2}{|c|}{ Distribution } \\
\hline & & & Region & Comment \\
\hline F. novicida & & Low & $\begin{array}{l}\text { Global: implied by isolates } \\
\text { from USA and Australia }\end{array}$ & Rarely isolated \\
\hline F. philomiragia & & Low & Northern hemisphere & Rarely isolated \\
\hline \multirow[t]{4}{*}{ F. tularensis } & tularensis A.I & Very high & $\begin{array}{l}\text { Central and Eastern } \\
\text { USA, California }\end{array}$ & $\begin{array}{l}\text { Distribution matches that of tick } \\
\text { vectors Amblyomma americanum } \\
\text { and Dermacentor variabilis (Farlow } \\
\text { et al., 2005) }\end{array}$ \\
\hline & tularensis A.II & $\begin{array}{l}\text { Moderate: lower than } \\
\text { subsp. holarctica } \\
\text { (Staples et al., 2006) }\end{array}$ & Western USA & $\begin{array}{l}\text { Distribution matches that of vectors } \\
\text { Dermacentor andersoni, Chrysops } \\
\text { discalis and mountain cottontail } \\
\text { rabbit (Farlow et al., 2005) }\end{array}$ \\
\hline & holarctica & High & $\begin{array}{l}\text { Northern hemisphere, } \\
\text { widespread }\end{array}$ & \\
\hline & mediasiatica & High & Central Asia & \\
\hline
\end{tabular}

disease is low (Helvaci et al., 2000; Tarnvik et al., 1996). These water-associated outbreaks are mainly caused by subspecies holarctica; subspecies tularensis has never been linked to water-borne infections (Oyston et al., 2004).

The type and severity of the disease is dependent on strain, dose and route of infection (Ellis et al., 2002). F. tularensis subspecies tularensis and holarctica cause the majority of reported cases, with subspecies tularensis causing the more severe disease of the two. Although tularaemia can be a severely debilitating or even fatal disease, especially when caused by $F$. tularensis subspecies tularensis, many cases of disease caused by lower-virulence strains are undiagnosed due to the non-specific nature of the symptoms. The incubation period is 3-5 days normally (range 1-21 days), and patients develop flu-like symptoms that may be protracted and relapsing if untreated (Evans et al., 1985).

Infection through the skin results in ulceroglandular tularaemia. This is the most common presentation of the disease and can arise following the bite of an infected vector or through direct contact with the flesh of infected animal (Ohara et al., 1991). A lesion develops at the site of infection, often a single papule that develops into an ulcer surrounded by a zone of inflammation (Oyston et al., 2004). The ulcer is relatively painless and heals within a week. Where no ulcer is reported, this is termed glandular tularaemia. Within a few days, the patient develops fever, chills, malaise, headaches and a sore throat. The local draining lymph nodes become enlarged and painful, like a bubo. Lymphadenopathy can take a significant period to resolve, even with treatment, and without treatment suppuration occurs in approximately $30 \%$ of cases (Helvaci et al., 2000; Kavanaugh, 1935). Less commonly, infection can occur through the conjunctiva. This is termed oculoglandular tularaemia and arises following direct contamination of the eye (Steinemann et al., 1999). The patient develops conjunctivitis in the infected eye, swollen eyelids and a purulent secretion. Untreated, the infection can spread to the local lymph nodes, similarly to ulceroglandular tularaemia. Ingestion of infected meat or water can result in oropharyngeal or gastrointestinal tularaemia (Stewart, 1996; Tarnvik et al., 1996). Ulcers, pharyngitis and swollen cervical lymph nodes develop, and a yellow-white pseudomembrane may be seen in oropharyngeal tularaemia. Gastrointestinal tularaemia can range from a mild but persistent diarrhoea to an acute fatal disease with extensive ulceration of the bowel, depending on the size of the infecting dose.

Inhalation of $F$. tularensis results in respiratory or pneumonic tularaemia. Respiratory tularaemia has been reported in farmers following activities such as making hay, where infectious dusts can be generated (Stewart, 1996; Syrjala et al., 1985). Other high-risk activities in endemic areas are lawn-mowing and brush cutting (Feldman et al., 2001; Matyas et al., 2007). For example in Martha's Vineyard, MA, USA, the majority of investigated cases were respiratory, in landscapers undertaking these types of work (Matyas et al., 2007). Pneumonia can also arise following haematogenous spread in other forms of tularaemia. Symptoms can be variable and depend on the virulence of the strain involved. Infection with the most highly virulent strains can have a case fatality rate of up to $30 \%$ if untreated, but antibiotic therapy reduces this to around $2 \%$ (Dennis et al., 2001). Presentation can range from a mild pneumonia to an acute infection with high fever, malaise, chills, cough, delirium and pulse-temperature dissociation. Radiological examination may reveal parenchymal infiltrates, most commonly in one lobe, and hilar lymphadenopathy may be present (Tarnvik \& Chu, 2007). The infectious dose required to cause disease by this route is very low (Dennis et al., 2001). The high infectivity combined with the morbidity and mortality caused by $F$. tularensis led to the organism being developed as a 
biological weapon by various nations, including the reported production of antibiotic-resistant strains (Dennis et al., 2001; Oyston et al., 2004). Since the events of September 2001 and the subsequent anthrax attacks on the USA, concern about the potential misuse of this organism has increased (Oyston et al., 2004). The associated increase in funding, particularly in the USA, has resulted in an influx of researchers working on the pathogen.

Tularaemia responds well to antibiotic therapy. As described above, the mortality rate of the more acute forms of the disease is reduced significantly if the patient receives suitable antibiotics. Historically aminoglycosides have been the drugs of choice. Although clinically effective, streptomycin is rarely used now due to problems of ototoxicity and nephrotoxicity (Titball et al., 2007). Similarly, although chloramphenicol has been used historically for treatment, it would be unlikely to be used as a first choice due to the possibility of irreversible effects on haematopoiesis (Titball et al., 2007). Gentamicin is a suitable alternative aminoglycoside, and has been used for treatment of pneumonic tularaemia on Martha's Vineyard (Matyas et al., 2007). Due to the requirement for parenteral dosing and monitoring of serum levels, aminoglycosides are now only used for the most serious cases. The tetracyclines have been associated with high relapse rates on withdrawal (Dennis et al., 2001). Doxycycline is effective in the treatment of tularaemia, but should be avoided for use in young children due to possible effects on developing teeth (Tarnvik \& Chu, 2007). Ciprofloxacin has been shown to be highly effective in oral therapy, and can be considered the current drug of choice for uncomplicated tularaemia (Johansson et al., 2001; Syrjala et al., 1991). It has shown to be effective in treating tularaemia in children, and may be suitable for use in pregnant women.

No licensed vaccine is available for prophylaxis of tularaemia. Killed cell preparations were reactogenic and of dubious efficacy (Foshay et al., 1942; Foshay, 1950), although studies in humans indicated that immunization with these vaccines reduced the number of infections and considerably modified the course of the disease (Foshay et al., 1942; Kadull et al., 1950). The identification of the antigens responsible for induction of a protective response has been an aim of research for 50 years. To date, the only protective antigen identified is LPS. In humans the predominant antibody response is to LPS. However, animal studies have shown that while immunization with LPS isolated from a live vaccine strain (LVS) induces protection against $F$. tularensis strains of low virulence, it is less effective at providing protection against strains of $F$. tularensis subspecies tularensis (Conlan et al., 2002; Fulop et al., 1995, 2001), and LPS isolated from strain SCHU S4 was similarly unable to protect immunized mice against homologous challenge (Prior et al., 2003). To date, many immunogenic proteins have been identified (Titball \& Petrosino, 2007), but none capable of inducing a protective immune response. This is probably a reflection that antibody is not sufficient to protect against tularaemia and a T-cell memory response must be induced for a vaccine to be protective (Tarnvik, 1989). A LVS was developed in the 1950s, and used extensively to vaccinate at-risk workers under 'investigational new drug' status, which resulted in a significant decrease in laboratoryacquired infections (Burke, 1977). The LVS vaccine provided good protection against an airborne challenge with 10 infectious doses of a virulent strain of $F$. tularensis subspecies tularensis, but only partial protection against 100 infectious doses and poor protection against 1000 infectious doses (McCrumb, 1961). Although LVS appears to be effective, there have been problems with the strain, such as reversion to virulence, mixed colony morphology and variable immunogenicity, and thus the LVS strain has failed to achieve licensing for human use (Oyston et al., 2004). The development of a candidate vaccine suitable for licensing is currently the focus of much research.

\section{A facultative intracellular pathogen}

F. tularensis can invade and multiply in a range of cell types (Anthony et al., 1991; Ben Nasr et al., 2006; Buddingh \& Womack, 1941; Councilman \& Strong, 1921; Francis, 1927; Lindemann et al., 2007; Shepard, 1959), but in vivo its primary target appears to be the macrophage (Fortier et al., 1994). Based on homology searches of the genome, $F$. tularensis does not produce any classical virulence factors, such as an exotoxin. Instead, the virulence of $F$. tularensis appears to stem from its ability to proliferate to large numbers within various host tissues and organs, thereby disrupting their normal functions and inducing a significant host inflammatory response that itself appears to contribute to the disease. The components of the organism that induce the inflammatory response are unknown, although LPS does not appear to be responsible (Ancuta et al., 1996; Sandstrom et al., 1992). However, differences in response observed between murine and human immune cells following exposure to LPS may indicate that the contribution of LPS to the inflammatory response may vary depending on the host (Rahhal et al., 2007). The innate response to Francisella has been shown to be mediated by interaction of bacterial components with TLR2 (Malik et al., 2006). Two lipoproteins, TUL4 and FTT1103, have been identified that interact with TLR2, which may be responsible for proinflammatory cytokine induction during infection (Thakran et al., 2007). A host protein, host matrix metalloprotein 9, has also been implicated in influencing development of morbidity following infection with Francisella (Malik et al., 2007). Host matrix metalloprotein 9, a member of the host matrix metalloproteinases family, is released by neutrophils and activated macrophages, and plays an important role in modulating leukocyte recruitment. Mice defective in production of the host matrix metalloprotein 9 were able to resolve infection, even with highly virulent subspecies tularensis strains, while normal expression rendered mice more susceptible to infection, with higher bacterial burdens 
and more extensive histopathology, morbidity and death (Malik et al., 2007).

As stated above, the LPS of Francisella is unique in that it does not bind to host molecules such as LPS-binding protein and TRL4 to trigger a proinflammatory response (Barker et al., 2006), nor does it bind to TLR2 (Hajjar et al., 2006). The lipid A from $F$. novicida and $F$. tularensis contains some unusual modifications (Phillips et al., 2004), and it has been suggested that Francisella may possess a novel system of LPS remodelling enzymes (Wang et al., 2006). The structure of the $\mathrm{O}$ antigen has been determined for $F$. tularensis subspecies tularensis and holarctica and F. novicida (Prior et al., 2003; Vinogradov et al., 2002, 2004). The O antigen for the two $F$. tularensis subspecies was identical, but that for $F$. novicida, while it shared may sugars with its close relatives, was structurally distinct. The structural differences seem to result in immunological differences, as the LPS did not induce cross-species protection (Shen et al., 2004; Thomas et al., 2007). Mutants of F. tularensis and F. novicida unable to synthesize $\mathrm{O}$ antigen were attenuated (Raynaud et al., 2007; Thomas et al., 2007), but the $\mathrm{O}$ antigen appeared to play a different role in the two species. The $\mathrm{O}$ antigen of $F$. tularensis appeared to be important for intracellular survival (Raynaud et al., 2007; Thomas et al., 2007), whereas the O antigen of $F$. novicida appeared to be critical for serum resistance and less important for intracellular survival (Thomas et al., 2007).

F. tularensis has a novel invasion strategy to enter host macrophages whereby it induces the macrophage to produce asymmetric spacious pseudopod loops (Clemens et al., 2005). This uptake is dependent on serum with complement activity, and host cell receptors for the complement factor C3, and appears to involve bacterial surface polysaccharides. Once inside the cell, the bacterium arrests maturation of the phagosome at a late endosomallike stage. Within 15-30 min, the phagosome is transiently acidified, and this acidification is essential for the subsequent escape of $F$. tularensis into the cytosol of the macrophage (Santic et al., 2008). The phagosome appears structurally unusual, appearing to acquire a dense fibrillar coat (Clemens et al., 2004). Eventually, the phagosomal membrane is degraded and the bacteria escape into the cytoplasm by 30-60 min after phagocytosis, and multiply to high levels in the cytoplasm (Checroun et al., 2006; Santic et al., 2007). Subsequently, it has been reported that the bacteria appear to re-enter the endocytic pathway by inducing an autophagy-mediated process, to reside in large double-membrane bound vacuoles, containing clusters of bacterial cells in each vacuole (Checroun et al., 2006), although this observation remains to be confirmed. Bacterial release is thought to occur following Francisellainduced apoptosis (Lai et al., 2001) and pyroptosis (Mariathasan et al., 2005). Pyroptosis is a newly described pathway of proinflammatory cell death (Fink \& Cookson, 2005) that results in the release of bacteria from within the infected cell. However, the final stages of the intracellular cycle are not well understood.
The acid phosphatase AcpA has been shown to play a key role in intracellular survival of Francisella, by inhibiting the respiratory burst generated by macrophages (Reilly et al., 1996). Deletion of acpA resulted in a mutant that was more susceptible than wild-type to killing by human macrophages and had decreased phosphatase activity associated with membrane fractions (Mohapatra et al., 2007). Additionally, the mutant showed a decreased ability to escape from the phagosome (Mohapatra et al., 2007). Several theories have been proposed to explain this observation (Mohapatra et al., 2007), one possibility being membrane disruption by phospholipase activity, which has been reported for AcpA in addition to its acid phosphatase activity (Reilly et al., 1996). Multiple acid phosphatases have been identified in the genome sequence of Francisella, but the contribution of each to the observed inhibition of the respiratory burst has not been determined. Francisella has also been shown to enter neutrophils without triggering the respiratory burst, by an unknown mechanism that inhibits NADPH oxidase assembly (McCaffrey \& Allen, 2006), and then escapes the phagosome to survive in the neutrophil cytoplasm. Thus Francisella belongs to a very small group of microbial pathogens able to avoid killing by neutrophils, and the importance of this observation to pathogenesis has yet to be determined.

The intracellular life cycle of $F$. tularensis is complex, and the genes involved with all stages have yet to be elucidated. The large Francisella pathogenicity island (FPI) was originally identified when inactivation of genes by random transposon mutagenesis resulted in an intracellular growth defect (Gray et al., 2002). For this reason the region was initially named the intracellular growth locus. The FPI contains 19 genes, including igl $A B C D$ and $p d p A B C D$, which have been shown to be essential for virulence (Nano et al., 2004). While F. novicida contains only a single copy of the FPI, subspecies tularensis and holarctica both possess two copies (Larsson et al., 2005). This may be one reason for the lower virulence of $F$. novicida. The functions of the proteins encoded by the FPI are currently the focus of much research. Bioinformatic analysis revealed the FPI to encode a putative type VI secretion system, similar to the systems involved in virulence of Pseudomonas aeruginosa (Mougous et al., 2006) and Vibrio cholerae (Pukatzki et al., 2006). The effectors secreted by the type VI secretion apparatus have yet to be determined. However, the IglABC proteins have received much attention previously due to their contribution to intracellular pathogenesis. IglA and IglB appear to associate in the bacterial cytoplasm (de Bruin et al., 2007) and are suggested to be involved in secretion. IglC is a $23 \mathrm{kDa}$ protein with no homologues identified to date. Francisella-induced apoptosis is dependent on IglC (Lai et al., 2004), and IglC appears to downregulate Toll-like receptor signalling to modulate the immune response (Telepnev et al., 2003). Genes within the FPI are regulated by MglA, which shows high similarity to SspA of Escherichia coli, a stringent response transcriptional regulator. Similarly to SspA, MglA interacts with 
RNA polymerase, but whereas SspA expression is induced at stationary phase $\mathrm{MglA}$ expression is maximal during lag and exponential phases of growth (Baron \& Nano, 1999; Brotcke et al., 2006). MglA expression is also increased during the early stages of macrophage infection, as would be predicted for a regulator of the genes of the intracellular growth locus (Baron \& Nano, 1999). Inactivation of MglA results in a significant intracellular growth defect and attenuation (Baron \& Nano, 1998; Lauriano et al., 2004). Transcriptional analysis indicated that a wide range of genes is regulated by MglA, including many outside of the FPI (Brotcke et al., 2006), such as the protease PepO and a putative $\beta$-glucosidase BglX.

In addition to the putative type VI secretion system carried by the FPI, Francisella has also been shown to secrete virulence factors by a type II secretion system. The type II secretion involves genes also involved in expression of type IV pili (Hager et al., 2006). These surface structures have been shown to play an important role in virulence for a range of Gram-negative pathogens (Craig et al., 2004). Several genes in the pili operons show extensive homology with type II secretion genes, and some pathogens, such as $P$. aeruginosa, may possess multiple type II secretion systems in addition to type IV pili (Stover et al., 2000). Deletion of genes involved in type IV pili biosynthesis is attenuating for subspecies holarctica (Forslund et al., 2006). Spontaneous recombination between direct repeats in the genome of a subspecies holarctica strain designated FSC074 led to the loss of pilA from the pilAEV cluster, resulting in loss of pili production and attenuation in mice challenged by the subcutaneous route of infection (Forslund et al., 2006). Inactivation of pil genes has different effects on virulence depending on the gene inactivated: subspecies holarctica pilC or pilQ mutants retain virulence, while the isogenic pilA mutant is attenuated (Forsberg \& Guina, 2007; Forslund et al., 2006). Unexpectedly, a F. novicida pilC mutant was more virulent than wild-type when tested in mice (Hager et al., 2006). The increased virulence appeared to be due to the effect of the mutation not on type IV pilus expression, but rather on the secretion of effector proteins. In contrast to the more virulent subspecies that do not appear to secrete proteins (Lee et al., 2006) in vitro, F. novicida secretes at least seven proteins detectable in culture supernatants, including chitinases, chitin binding protein, PepO and BglX (Hager et al., 2006). The increased virulence of the F. novicida pilC mutant was linked to a decrease in PepO secretion (Hager et al., 2006). PepO has homology with proteins involved with cleavage of proendothelin. The endothelin thus produced is a potent vasoconstrictor. Thus PepO secretion would result in localized vasoconstriction and therefore limit dissemination of $F$. novicida from the local site of infection, but abrogating PepO secretion by mutating the pil genes of the secretion machinery would increase dissemination, and thus virulence. The genome sequences of subspecies holarctica and tularensis revealed that pepO has been mutated so it is no longer expressed by these strains, and this appears to have been a key step in the evolution to high virulence in mammalian hosts.

A putative type I secretion system has been proposed for $F$. tularensis, although this remains to be proven. F. tularensis possesses two orthologues of the E. coli TolC protein, TolC and FtlC (Gil et al., 2006). In E. coli, TolC is the outer membrane channel component used by type I secretion systems and multidrug efflux pumps. Inactivation of tolC and $f t l C$ increased sensitivity to a range of toxic compounds, indicating a role in efflux, but only the tolC mutant was attenuated (Gil et al., 2006). This may reflect differences in substrates between TolC and FtlC efflux pumps, or it may indicate that $F$. tularensis possesses a type I secretion system, even though the other components of type I secretion have not been identified by homology as yet.

Iron acquisition is recognized as an important virulence trait of many intracellular pathogens, but little was known until recently about how Francisella acquires iron from the mammalian host. Transcriptional analysis of bacteria grown in media with low iron concentrations revealed an iron-responsive operon involved in siderophore production (Deng et al., 2006; Milne et al., 2007). Inactivation of a gene involved in siderophore production resulted in an intracellular growth defect in F. novicida, but not in the subspecies holarctica strain LVS (Deng et al., 2006). However, the siderophore production of the wild-type LVS strain was significantly reduced compared to that of $F$. novicida, which suggests that mutations elsewhere in the genome were affecting siderophore activity in LVS. The iron-regulated operon also included the siderophore receptor required for uptake of the siderophore-iron complex (Milne et al., 2007). Inactivation of the gene encoding the receptor resulted in attenuation of F. novicida in mice, indicating that iron acquisition is a virulence trait in Francisella similarly to other intracellular pathogens.

A significant proportion of $F$. tularensis genes are annotated as hypothetical proteins with unknown function, and elucidation of their roles will help in understanding this enigmatic pathogen. Several whole genome sequences are now available for different strains and subspecies of $F$. tularensis (Table 2). Comparison of the subspecies tularensis strain SCHU S4 with subspecies holarctica strains LVS and OSU18 revealed that, despite high nucleotide identity between the strains, significant rearrangements were observed between the two subspecies (Petrosino et al., 2006). There were 51 syntenic blocks rearranged between SCHU S4 and OSU18 genomes. The rearrangements were due to homologous recombination between the numerous copies of insertion sequence elements around the genome, and multiple copies of rRNA sequences. Despite the repeated DNA sequences being present in subspecies holarctica, no rearrangements were found between the minimally passaged isolate OSU18 and LVS, a highly passaged and attenuated strain (Petrosino et al., 2006). The reason for this genomic stability in subspecies holarctica is not known. Detailed 
Table 2. Francisella genome sequencing projects listed on the National Centre for Biotechnology Information database

\begin{tabular}{|c|c|c|c|}
\hline Sequenced strain & Length (nt) & Sequencing centre & Comment \\
\hline F. tularensis subsp. tularensis SCHU S4 & 1892819 & Swedish Defence Research Agency & $\begin{array}{l}\text { Fully virulent, A.I clade, laboratory } \\
\text { passaged }\end{array}$ \\
\hline F. tularensis subsp. holarctica OSU18 & 1895727 & Baylor College of Medicine & Minimally passaged \\
\hline F. tularensis subsp. tularensis FSC198 & 1892616 & University of Birmingham & European isolate \\
\hline F. tularensis subsp. holarctica LVS & 1895994 & $\begin{array}{l}\text { Lawrence Livermore National } \\
\text { Laboratory }\end{array}$ & Attenuated, highly passaged \\
\hline F. novicida $\mathrm{U} 112$ & 1910031 & University of Washington & \\
\hline F. tularensis subsp. holarctica FTA & 1890909 & $\begin{array}{l}\text { US Department of Energy Joint } \\
\text { Genome Institute }\end{array}$ & \\
\hline F. tularensis subsp. tularensis WY96-3418 & 1898476 & $\begin{array}{l}\text { Translational Genomics Research } \\
\text { Institute }\end{array}$ & $\begin{array}{l}\text { A.II clade, CDC collection, isolated } \\
\text { from a finger wound in } 1996 \\
\text { (Beckstrom-Sternberg et al., 2007) }\end{array}$ \\
\hline \multicolumn{4}{|l|}{ Unfinished genomes } \\
\hline F. tularensis subsp. holarctica FSC200 & 1790358 & University of Washington & Minimally passaged European isolate \\
\hline F. tularensis subsp. tularensis FSC33 & 1844205 & $\begin{array}{l}\text { Broad Institute Genome } \\
\text { Sequencing Platform }\end{array}$ & $\begin{array}{l}\text { Fully virulent strain, isolated from a } \\
\text { squirrel in Georgia, USA } \\
\text { (Johansson et al., 2000) }\end{array}$ \\
\hline F. novicida GA99-3548 & 1845491 & $\begin{array}{l}\text { Broad Institute Genome } \\
\text { Sequencing Platform }\end{array}$ & \\
\hline F. novicida GA99-3549 & 1897440 & $\begin{array}{l}\text { Broad Institute Genome } \\
\text { Sequencing Platform }\end{array}$ & \\
\hline
\end{tabular}

CDC, Centers for Disease Control and Prevention.

comparison of the two subspecies holarctica strains revealed that LVS and OSU18 are very nearly identical. Considering that LVS was derived in Russia from a European subspecies holarctica strain and OSU18 was isolated over three decades later in Oklahoma, USA, this high level of identity is striking, but typing has suggested that subspecies holarctica strains show little genetic diversity worldwide (Johansson et al., 2004). It appears, therefore, that the relative attenuation of LVS is due to small sequence variations, insertions and deletions. Comparison of the LVS with the genomes of minimally passaged holarctica strains identified, for example, mutations in genes encoding the type IV pili cluster discussed above, a tyrosine phosphoprotein, a multi-drug efflux pump and a glycosyltransferase (Petrosino et al., 2006; Rohmer et al., 2006). Individually these may not be responsible for attenuation of LVS, but could each contribute subtly and in part to the phenotype.

Comparison of virulent and attenuated strains identified another locus of interest. An empirically attenuated mutant of SCHU S4 possessed a deletion spanning two adjacent genes, FTT0918 and FTT0919, resulting in a novel ORF that encodes a hybrid protein consisting of the $\mathrm{N}$ terminus of the protein encoded by the former gene and the $\mathrm{C}$ terminus of the protein encoded by the latter gene (Twine et al., 2005). The attenuated subspecies holarctica strain LVS possesses a similar deletion. Isogenic deletion of FTT0918, but not FTT0919, severely attenuated SCHU S4. Combined restoration of FTT0918 and pilA genes in LVS by complementation resulted in a fully virulent phenotype, indicating that these two mutations contribute significantly to the observed attenuation of LVS. The function of FTT0918 is not known. However, although it has no homology to any other protein in the database, it was identified as being one member of a protein family along with FTT0919, FTT0025, FTT0267 and FTT0602 (Larsson et al., 2005).

With the availability of genome sequence data, the main impediment to understanding the molecular basis of Francisella virulence was the paucity of molecular tools with which to manipulate the pathogen, particularly for global mutagenesis approaches. However, shuttle plasmids (Bina et al., 2006; LoVullo et al., 2006; Maier et al., 2004; Rasko et al., 2007), transposons (Gallagher et al., 2007; Kawula et al., 2004; Maier et al., 2006; Weiss et al., 2007) and allelic replacement methodologies (Golovliov et al., 2003; Lauriano et al., 2003; Twine et al., 2005) have all recently been developed. Global mutagenesis of $F$. tularensis subspecies tularensis strain SCHU S4 (Qin \& Mann, 2006), subspecies holarctica strain LVS (Maier et al., 2007; Su et al., 2007) and F. novicida (Gallagher et al., 2007; Tempel et al., 2006; Weiss et al., 2007) has resulted in the identification of genes essential for growth in vitro (Gallagher et al., 2007), for intracellular survival in hepatic cells (Qin \& Mann, 2006) or macrophages (Maier et al., 2007; Tempel et al., 2006) and in vivo (Su et al., 2007; Weiss et al., 2007). The genes identified as important to the intracellular pathogenesis of Francisella could be targets for novel antimicrobial development (Gallagher et al., 2007) or a novel attenuated vaccine. In addition these studies have 
provided information about the mechanisms of pathogenesis employed by the organism. For example, one of these global mutagenesis studies identified that bacteria injected subcutaneously passed through a bottleneck before systemic dissemination occurred (Weiss et al., 2007). This bottleneck was not apparent when the mice were challenged by the intranasal route (Su et al., 2007) or intraperitoneally (Weiss et al., 2007). Similar bottlenecks have been reported for enteric pathogens invading from the gut (Mecsas et al., 2001). The nature of the bottleneck is not known, and shows that we still have much to learn about the life of the pathogen in vivo.

\section{Conclusion}

Until recently, our understanding of the molecular mechanisms of virulence of Francisella was significantly impaired by a lack of molecular tools and information. As indicated above, multiple genome sequences are becoming available, but low levels of homology between Francisella genes and those of other pathogens have resulted in as many questions being raised as answered. New molecular tools are being developed, and our ability to manipulate the pathogen is improving. Several studies now report global approaches to identifying genes involved in virulence and particularly genes involved in intracellular multiplication. As such, we are getting closer to addressing key issues such as the need for an effective licensable vaccine. It appears we are still some way from understanding the pathogenesis of the organism however.

\section{References}

Ancuta, P., Pedron, T., Girard, R., Sandstrom, G. \& Chaby, R. (1996). Inability of the Francisella tularensis lipopolysaccharide to mimic or to antagonize the induction of the cell activation by endotoxins. Infect Immun 64, 2041-2046.

Anthony, L. D., Burke, R. D. \& Nano, F. E. (1991). Growth of Francisella spp. in rodent macrophages. Infect Immun 59, 3291-3296.

Barker, J. H., Weiss, J., Apicella, M. A. \& Nauseef, W. M. (2006). Basis for the failure of Francisella tularensis lipopolysaccharide to prime human polymorphonuclear leukocytes. Infect Immun 74, 3277-3284.

Baron, G. S. \& Nano, F. E. (1998). MgIA and MgIB are required for the intramacrophage growth of Francisella novicida. Mol Microbiol 29, 247-259.

Baron, G. S. \& Nano, F. E. (1999). An erythromycin resistance cassette and mini-transposon for constructing transcriptional fusions to cat. Gene 229, 59-65.

Beckstrom-Sternberg, S. M., Auerbach, R. K., Godbole, S., Pearson, J. V., Beckstrom-Sternberg, J. S., Deng, Z., Munk, C., Kubota, K., Zhou, Y. \& other authors (2007). Complete genomic characterization of a pathogenic A.II strain of Francisella tularensis subspecies tularensis. PLoS ONE 2, e947.

Ben Nasr, A., Haithcoat, J., Masterson, J. E., Gunn, J. S., Eaves-Pyles, T. \& Klimpel, G. R. (2006). Critical role for serum opsonins and complement receptors CR3 (CD11b/CD18) and CR4 (CD11c/CD18) in phagocytosis of Francisella tularensis by human dendritic cells (DC): uptake of Francisella leads to activation of immature DC and intracellular survival of the bacteria. J Leukoc Biol 80, 774-786.
Bina, X. R., Wang, C., Miller, M. A. \& Bina, J. E. (2006). The Bla2 $\beta$ lactamase from the live-vaccine strain of Francisella tularensis encodes a functional protein that is only active against penicillin-class betalactam antibiotics. Arch Microbiol 186, 219-228.

Boyce, J. M. (1975). Recent trends in the epidemiology of tularemia in the United States. J Infect Dis 131, 197-199.

Brotcke, A., Weiss, D. S., Kim, C. C., Chain, P., Malfatti, S., Garcia, E. \& Monack, D. M. (2006). Identification of MglA-regulated genes reveals novel virulence factors in Francisella tularensis. Infect Immun 74, 6642-6655.

Buddingh, G. J. \& Womack, F. C., Jr (1941). Observations on the infection of chick embryos with Bacterium tularense, Brucella, and Pasteurella pestis. J Exp Med 74, 213-222.

Burke, D. S. (1977). Immunization against tularemia: analysis of the effectiveness of live Francisella tularensis vaccine in prevention of laboratory-acquired tularemia. J Infect Dis 135, 55-60.

Checroun, C., Wehrly, T. D., Fischer, E. R., Hayes, S. F. \& Celli, J. (2006). Autophagy-mediated reentry of Francisella tularensis into the endocytic compartment after cytoplasmic replication. Proc Natl Acad Sci U S A 103, 14578-14583.

Clemens, D. L., Lee, B. Y. \& Horwitz, M. A. (2004). Virulent and avirulent strains of Francisella tularensis prevent acidification and maturation of their phagosomes and escape into the cytoplasm in human macrophages. Infect Immun 72, 3204-3217.

Clemens, D. L., Lee, B. Y. \& Horwitz, M. A. (2005). Francisella tularensis enters macrophages via a novel process involving pseudopod loops. Infect Immun 73, 5892-5902.

Conlan, J. W., Shen, H., Webb, A. \& Perry, M. B. (2002). Mice vaccinated with the O-antigen of Francisella tularensis LVS lipopolysaccharide conjugated to bovine serum albumin develop varying degrees of protective immunity against systemic or aerosol challenge with virulent type A and type B strains of the pathogen. Vaccine 20, 3465-3471.

Councilman, W. T. \& Strong, R. P. (1921). Plague-like infections in rodents. Trans Assoc Am Physicians 36, 135-143.

Craig, L., Pique, M. E. \& Tainer, J. A. (2004). Type IV pilus structure and bacterial pathogenicity. Nat Rev Microbiol 2, 363-378.

de Bruin, O. M., Ludu, J. S. \& Nano, F. E. (2007). The Francisella pathogenicity island protein IglA localizes to the bacterial cytoplasm and is needed for intracellular growth. BMC Microbiol 7, 1.

Deng, K., Blick, R. J., Liu, W. \& Hansen, E. J. (2006). Identification of Francisella tularensis genes affected by iron limitation. Infect Immun 74, 4224-4236.

Dennis, D. T., Inglesby, T. V., Henderson, D. A., Bartlett, J. G., Ascher, M. S., Eitzen, E., Fine, A. D., Friedlander, A. M., Hauer, J. \& other authors (2001). Tularemia as a biological weapon: Medical and Public Health Management. JAMA 285, 2763-2773.

Dorofe'ev, K. A. (1947). Classification of the causative agent of tularemia. Symp Res Works Inst Epidemiol Mikrobiol Chita 1, 170-180.

Ellis, J., Oyston, P. C. F., Green, M. \& Titball, R. W. (2002). Tularemia. Clin Microbiol Rev 15, 631-646.

Evans, M. E., Gregory, D. W., Schaffner, W. \& McGee, Z. A. (1985). Tularemia: a 30 year experience with 88 cases. Medicine (Baltimore) 64, 251-269.

Farlow, J., Wagner, D. M., Dukerich, M., Stanley, M., Chu, M., Kubota, K., Petersen, J. \& Keim, P. (2005). Francisella tularensis in the United States. Emerg Infect Dis 11, 1835-1841.

Feldman, K. A., Enscore, R. E., Lathrop, S. L., Matyas, B. T., McGuill, M., Schriefer, M. E., Stiles-Enos, D., Dennis, D. T., Petersen, L. R. \& Hayes, E. B. (2001). An outbreak of primary pneumonic tularemia on Martha's Vineyard. N Engl J Med 345, 1601-1637. 
Fink, S. L. \& Cookson, B. T. (2005). Apoptosis, pyroptosis, and necrosis: mechanistic description of dead and dying eukaryotic cells. Infect Immun 73, 1907-1916.

Forsberg, A. \& Guina, T. (2007). Type II secretion and type IV pili of Francisella. Ann N Y Acad Sci 1105, 187-201.

Forslund, A. L., Kuoppa, K., Svensson, K., Salomonsson, E., Johansson, A., Byström, M., Oyston, P. C. F., Michell, S. L., Titball, R. W. \& other authors (2006). Direct repeat-mediated deletion of a type IV pilin gene results in major virulence attenuation of Francisella tularensis. Mol Microbiol 59, 1818-1830.

Forsman, M., Sandstrom, G. \& Sjostedt, A. (1994). Analysis of $16 S$ ribosomal DNA sequences of Francisella strains and utilization for determination of the phylogeny of the genus and for identification of strains by PCR. Int J Syst Bacteriol 44, 38-46.

Fortier, A. H., Green, S. J., Polsinelli, T., Jones, T. R., Crawford, R. M., Leiby, D. A., Elkins, K. L., Meltzer, M. S. \& Nacy, C. A. (1994). Life and death of an intracellular pathogen: Francisella tularensis and the macrophage. Immunol Ser 60, 349-361.

Foshay, L. (1950). Tularemia. Annu Rev Microbiol 4, 313-330.

Foshay, L., Hesselbrock, W. H., Wittenberg, H. J. \& Rodenberg, A. H. (1942). Vaccine prophylaxis against tularemia in man. Am J Public Health 32, 1131-1145.

Francis, E. (1927). Microscopic changes of tularemia in the tick Dermacentor andersoni and the bedbug Cimex lectularius. Public Health Rep 42, 2763-2772.

Fulop, M., Manchee, R. \& Titball, R. (1995). Role of lipopolysaccharide and a major outer-membrane protein from Francisella tularensis in the induction of immunity against tularemia. Vaccine 13, 1220-1225.

Fulop, M., Mastroeni, P., Green, M. \& Titball, R. W. (2001). Role of antibody to lipopolysaccharide in protection against low- and highvirulence strains of Francisella tularensis. Vaccine 19, 4465-4472.

Gallagher, L. A., Ramage, E., Jacobst, M. A., Kaul, R., Brittnacher, M. \& Manoil, C. (2007). A comprehensive transposon mutant library of Francisella novicida, a bioweapon surrogate. Proc Natl Acad Sci U S A 104, 1009-1014.

Gil, H., Platz, G. J., Forestal, C. A., Monfett, M., Bakshi, C. S., Seliati, T. J., Furie, M. B., Benach, J. L. \& Thanassi, D. G. (2006). Deletion of TolC orthologs in Francisella tularensis identifies roles in multidrug resistance and virulence. Proc Natl Acad Sci U S A 103, 12897-12902.

Golovliov, I., Sjostedt, A., Mokrievich, A. \& Pavlov, V. (2003). A method for allelic replacement in Francisella tularensis. FEMS Microbiol Lett 222, 273-280.

Gray, C. G., Cowley, S. C., Cheung, K. K. M. \& Nano, F. E. (2002). The identification of five genetic loci of Francisella novicida associated with intracellular growth. FEMS Microbiol Lett 215, 53-56.

Hager, A. J., Bolton, D. L., Pelletier, M. R., Brittnacher, M. J., Gallagher, L. A., Kaul, R., Skerrett, S. J., Miller, S. I. \& Guina, T. (2006). Type IV pili-mediated secretion modulates Francisella virulence. Mol Microbiol 62, 227-237.

Hajjar, A. M., Harvey, M. D., Shaffer, S. A., Goodlett, D. R., Sjostedt, A., Edebro, H., Forsman, M., Bystrom, M., Pelletier, M. \& other authors (2006). Lack of in vitro and in vivo recognition of Francisella tularensis subspecies lipopolysaccharide by Toll-like receptors. Infect Immun 74, 6730-6738.

Helvaci, S., Gedikoglu, S., Akalin, H. \& Oral, H. B. (2000). Tularemia in Bursa, Turkey: 205 cases in ten years. Eur J Epidemiol 16, 271-276.

Hood, A. M. (1977). Virulence factors of Francisella tularensis. J Hyg (Lond) 79, 47-65.

Johansson, A., Ibrahim, A., Goransson, I., Eriksson, U., Gurycova, D., Clarridge, J. E., III \& Sjostedt, A. (2000). Evaluation of PCR-based methods for discrimination of Francisella species and subspecies and development of a specific PCR that distinguishes the two major subspecies of Francisella tularensis. J Clin Microbiol 38, 4180-4185.

Johansson, A., Berglund, L., Sjostedt, A. \& Tarnvik, A. (2001). Ciprofloxacin for treatment of tularemia. Clin Infect Dis 33, 267-268.

Johansson, A., Farlow, J., Larsson, P., Dukerich, M., Chambers, E., Bystrom, M., Fox, J., Chu, M., Forsman, M. \& other authors (2004). Worldwide genetic relationships among Francisella tularensis isolates determined by multiple-locus variable-number tandem repeat analysis. J Bacteriol 186, 5808-5818.

Kadull, P. J., Reames, H. R., Coriell, L. L. \& Foshay, L. (1950). Studies on tularemia. V. Immunisation of man. J Immunol 65, 425-435.

Kavanaugh, C. N. (1935). Tularemia. A consideration of one hundred and twenty-three cases, with observations at autopsy in one. Arch Intern Med 55, 61-85.

Kawula, T. H., Hall, J. D., Fuller, J. R. \& Craven, R. R. (2004). Use of transposon-transposase complexes to create stable insertion mutant strains of Francisella tularensis LVS. Appl Environ Microbiol 70, 6901-6904.

Keim, P., Johansson, A. \& Wagner, D. M. (2007). Molecular epidemiology, evolution, and ecology of Francisella. Ann N Y Acad Sci 1105, 30-66.

Lai, X. H., Golovliov, I. \& Sjostedt, A. (2001). Francisella tularensis induces cytopathogenicity and apoptosis in murine macrophages via a mechanism that requires intracellular bacterial multiplication. Infect Immun 69, 4691-4694.

Lai, X. H., Golovliov, I. \& Sjostedt, A. (2004). Expression of IglC is necessary for intracellular growth and induction of apoptosis in murine macrophages by Francisella tularensis. Microb Pathog 37, 225-230.

Larsson, P., Oyston, P. C. F., Chain, P., Chu, M., Duffield, M. L., Gabbert, N. M., Fuxelius, H. H., Garcia, E., Halltorp, G. \& other authors (2005). The complete genome sequence of Francisella tularensis, the causative agent of tularemia. Nat Genet 37, 153-159.

Lauriano, C. M., Barker, J. R., Nano, F. E., Arulanandarn, B. P. \& Klose, K. E. (2003). Allelic exchange in Francisella tularensis using PCR products. FEMS Microbiol Lett 229, 195-202.

Lauriano, C. M., Barker, J. R., Yoon, S. S., Nano, F. E., Arulanandam, B. P., Hassettt, D. J. \& Klose, K. E. (2004). MglA regulates transcription of virulence factors necessary for Francisella tularensis intraamoebae and intramacrophage survival. Proc Natl Acad Sci U S A 101, 4246-4249.

Lee, B. Y., Horwitz, M. A. \& Clemens, D. L. (2006). Identification, recombinant expression, immuno localization in macrophages, and T-cell responsiveness of the major extracellular proteins of Francisella tularensis. Infect Immun 74, 4002-4013.

Levesque, B., de Serres, G., Higgins, R., D'Halewyn, M. A., Atsorb, H., Grondin, J., Major, M., Garvie, M. \& Duval, B. (1995). Seroepidemiologic study of three zoonoses (leptospirosis, Q fever, and tularemia) among trappers in Québec, Canada. Clin Diagn Lab Immunol 2, 496-498.

Lindemann, S. R., McLendon, M. K., Apicella, M. A. \& Jones, B. D. (2007). An in vitro model system used to study adherence and invasion of Francisella tularensis live vaccine strain in nonphagocytic cells. Infect Immun 75, 3178-3182.

LoVullo, E. D., Sherrill, L. A., Perez, L. L. \& Pavelka, M. S. (2006). Genetic tools for highly pathogenic Francisella tularensis subsp. tularensis. Microbiology 152, 3425-3435.

Maier, T. M., Havig, A., Casey, M., Nano, F. E., Frank, D. W. \& Zahrt, T. C. (2004). Construction and characterisation of a highly efficient Francisella shuttle plasmid. Appl Environ Microbiol 70, 7511-7519.

Maier, T. M., Pechous, R., Casey, M., Zahrt, T. C. \& Frank, D. W. (2006). In vivo Himarl-based transposon mutagenesis of Francisella tularensis. Appl Environ Microbiol 72, 1878-1885. 
Maier, T. M., Casey, M., Becker, R., Dorsey, C., Glass, E., Maltsev, N., Zahrt, T. C. \& Frank, D. W. (2007). Identification of Francisella tularensis Himar1-based transposon mutants defective for replication in macrophages. Infect Immun 75, 5376-5389.

Malik, M., Bakshi, C. S., Sahay, B., Shah, A., Lotz, S. A. \& Sellati, T. J. (2006). Toll-like receptor 2 is required for control of pulmonary infection with Francisella tularensis. Infect Immun 74, 3657-3662.

Malik, M., Bakshi, C. S., McCabe, K., Catlett, S. V., Shah, A., Singh, R., Jackson, P. L., Gaggar, A., Metzger, D. W. \& other authors (2007). Matrix metalloproteinase 9 activity enhances host susceptibility to pulmonary infection with type A and B strains of Francisella tularensis. J Immunol 178, 1013-1020.

Mariathasan, S., Weiss, D. S., Dixit, V. M. \& Monack, D. M. (2005). Innate immunity against Francisella tularensis is dependent on the ASC/caspase-1 axis. J Exp Med 202, 1043-1049.

Matyas, B. T., Nieder, H. S. \& Telford, S. R., III (2007). Pneumonic tularemia on Martha's Vineyard - clinical, epidemiologic, and ecological characteristics. Ann N Y Acad Sci 1105, 351-377.

McCaffrey, R. L. \& Allen, L.-A. H. (2006). Pivotal advance: Francisella tularensis LVS evades killing by human neutrophils via inhibition of the respiratory burst and phagosome escape. J Leukoc Biol 80, 1224-1230.

McCoy, G. W. \& Chapin, C. W. (1912). Further observations on a plague-like disease of rodents with a preliminary note on the causative agent, Bacterium tularense. J Infect Dis 10, 61-72.

McCrumb, F. R. (1961). Aerosol infection of man with Pasteurella tularensis. Bacteriol Rev 25, 262-267.

Mecsas, J., Bilis, I. \& Falkow, S. (2001). Identification of attenuated Yersinia pseudotuberculosis strains and characterization of an orogastric infection in BALB/c mice on day 5 postinfection by signaturetagged mutagenesis. Infect Immun 69, 2779-2787.

Milne, T. S., Michell, S. L., Diaper, H., Wikstrom, P., Svensson, K., Oyston, P. C. F. \& Titball, R. W. (2007). A $55 \mathrm{kDa}$ hypothetical membrane protein is an iron-regulated virulence factor of Francisella tularensis subsp. novicida U112. J Med Microbiol 56, 1268-1276.

Mohapatra, N. P., Balagopal, A., Soni, S., Schlesinger, L. S. \& Gunn, J. S. (2007). AcpA is a Francisella acid phosphatase that affects intramacrophage survival and virulence. Infect Immun 75, 390-396.

Mörner, T. (1992). The ecology of tularemia. Rev Sci Tech 11, 1123-1130.

Mougous, J. D., Cuff, M. E., Raunser, S., Shen, A., Zhou, M., Gifford, C. A., Goodman, A. L., Joachimiak, G., Ordonez, C. L. \& other authors (2006). A virulence locus of Pseudomonas aeruginosa encodes a protein secretion apparatus. Science 312, 1526-1530.

Nano, F. E., Zhang, N., Cowley, S. C., Klose, K. E., Cheung, K. K. M., Roberts, M. J., Ludu, J. S., Letendre, G. W., Meierovics, A. I. \& other authors (2004). A Francisella tularensis pathogenicity island required for intramacrophage growth. J Bacteriol 186, 6430-6436.

Nylund, A., Ottem, K. F., Watanabe, K., Karlsbakk, E. \& Krossoy, B. (2006). Francisella sp (family Francisellaceae) causing mortality in Norwegian cod (Gadus morhua) farming. Arch Microbiol 185, 383-392.

Ohara, Y., Sato, T., Fujita, H., Ueno, T. \& Homma, M. (1991). Clinical manifestations of tularemia in Japan - analysis of 1355 cases observed between 1924 and 1987. Infection 19, 14-17.

Ostland, V. E., Stannard, J. A., Creek, J. J., Hedrick, R. P., Ferguson, H. W., Carlberg, J. M. \& Westerman, M. E. (2006). Aquatic Francisellalike bacterium associated with mortality of intensively cultured hybrid striped bass Morone chrysops $\times$ M. saxatilis. Dis Aquat Organ 72, 135-145.

Oyston, P. C. F., Sjostedt, A. \& Titball, R. W. (2004). Tularemia: bioterrorism defence renews interest in Francisella tularensis. Nat Rev Microbiol 2, 967-978.
Petrosino, J. F., Xiang, Q., Karpathy, S. E., Jiang, H. Y., Yerrapragada, S., Liu, Y. M., Gioia, J., Hemphill, L., Gonzalez, A. \& other authors (2006). Chromosome rearrangement and diversification of Francisella tularensis revealed by the type B (OSU18) genome sequence. J Bacteriol 188, 6977-6985.

Phillips, N. J., Schilling, B., McLendon, M. K., Apicella, M. A. \& Gibson, B. W. (2004). Novel modification of lipid A of Francisella tularensis. Infect Immun 72, 5340-5348.

Prior, J. L., Prior, R. G., Hitchen, P. G., Diaper, H., Griffin, K. F., Morris, H. R., Dell, A. \& Titball, R. W. (2003). Characterization of the $O$ antigen gene cluster and structural analysis of the $\mathrm{O}$ antigen of Francisella tularensis subsp. tularensis. J Med Microbiol 52, 845-851.

Pukatzki, S., Ma, A. T., Sturtevant, D., Krastins, B., Sarracino, D., Nelson, W. C., Heidelberg, J. F. \& Mekalanos, J. J. (2006). Identification of a conserved bacterial protein secretion system in Vibrio cholerae using the Dictyostelium host model system. Proc Natl Acad Sci U S A 103, 1528-1533.

Qin, A. \& Mann, B. J. (2006). Identification of transposon insertion mutants of Francisella tularensis tularensis strain Schu S4 deficient in intracellular replication in the hepatic cell line HepG2. BMC Microbiol 6, 69.

Rahhal, R. M., Bush, T. J. V., McLendon, M. K., Apicella, M. A. \& Bishop, G. A. (2007). Differential effects of Francisella tularensis lipopolysaccharide on B lymphocytes. J Leukoc Biol 82, 813-820.

Rasko, D. A., Esteban, C. D. \& Sperandio, V. (2007). Development of novel plasmid vectors and a promoter trap system in Francisella tularensis compatible with the pFLN10 based plasmids. Plasmid 58, 159-166.

Raynaud, C., Meibom, K. L., Lety, M. A., Dubail, I., Candela, T., Frapy, E. \& Charbit, A. (2007). Role of the wbt locus of Francisella tularensis in lipopolysaccharide $\mathrm{O}$-antigen biogenesis and pathogenicity. Infect Immun 75, 536-541.

Reilly, T. J., Baron, G. S., Nano, F. E. \& Kuhlenschmidt, M. S. (1996). Characterization and sequencing of a respiratory burst-inhibiting acid phosphatase from Francisella tularensis. J Biol Chem 271, 1097310983.

Rohmer, L., Brittnacher, M., Svensson, K., Buckley, D., Haugen, E., Zhou, Y., Chang, J., Levy, R., Hayden, H. \& other authors (2006). Potential source of Francisella tularensis live vaccine strain attenuation determined by genome comparison. Infect Immun 74, 6895-6906.

Sandstrom, G., Sjostedt, A., Johansson, T., Kuoppa, K. \& Williams, J. C. (1992). Immunogenicity and toxicity of lipopolysaccharide from Francisella tularensis LVS. FEMS Microbiol Immunol 5, 201-210.

Santic, M., Molmeret, M., Barker, J. R., Klose, K. E., Dekanic, A., Doric, M. \& Abu Kwaik, Y. (2007). A Francisella tularensis pathogenicity island protein essential for bacterial proliferation within the host cell cytosol. Cell Microbiol 9, 2391-2403.

Santic, M., Asare, R., Skrobonja, I., Jones, S. \& Kwaik, Y. A. (2008). Acquisition of the vATPase proton pump and phagosome acidification is essential for escape of Francisella tularensis into the macrophage cytosol. Infect Immun (in press).

Shen, H., Chen, W. X. \& Conlan, J. W. (2004). Mice sublethally infected with Francisella novicida U112 develop only marginal protective immunity against systemic or aerosol challenge with virulent type A or B strains of F. tularensis. Microb Pathog 37, 107-110.

Shepard, C. C. (1959). Nonacid-fast bacteria and HeLa cells: their uptake and subsequent intracellular growth. J Bacteriol 77, 701-714.

Sjostedt, A. (2005). Family XVII. Francisellaceae, genus I. Francisella. In Bergey's Manual of Systematic Bacteriology, pp. 200-210. Edited by 
D. J. Brenner, N. R. Krieg, J. T. Staley \& G. M. Garrity. New York: Springer.

Sjostedt, A. (2007). Tularemia: history, epidemiology, pathogen physiology, and clinical manifestations. Ann N Y Acad Sci 1105, 1-29.

Staples, J. E., Kubota, K. A., Chalcraft, L. G., Mead, P. S. \& Petersen, J. M. (2006). Epidemiologic and molecular analysis of human tularemia, United States, 1964-2004. Emerg Infect Dis 12, 1113-1118.

Steinemann, T. L., Sheikholeslami, M. R., Brown, H. H. \& Bradsher, R. W. (1999). Oculoglandular tularemia. Arch Ophthalmol 117, 132-133.

Stewart, S. J. (1996). Tularemia: association with hunting and farming. FEMS Immunol Med Microbiol 13, 197-199.

Stover, C. K., Pham, X. Q., Erwin, A. L., Mizoguchi, S. D., Warrener, P., Hickey, M. J., Brinkman, F. S. L., Hufnagle, W. O., Kowalik, D. J. \& other authors (2000). Complete genome sequence of Pseudomonas aeruginosa PAO1, an opportunistic pathogen. Nature 406, 959-964.

Su, J., Yang, J., Zhao, D., Kawula, T. H., Banas, J. A. \& Zhang, J.-R. (2007). Genome-wide identification of Francisella tularensis virulence determinants. Infect Immun 75, 3089-3101.

Syrjala, H., Kujala, P., Myllyla, V. \& Salminen, A. (1985). Airborne transmission of tularemia in farmers. Scand J Infect Dis 17, 371-375.

Syrjala, H., Schildt, R. \& Raisainen, S. (1991). In vitro susceptibility of Francisella tularensis to fluoroquinolones and treatment of tularemia with norfloxacin and ciprofloxacin. Eur J Clin Microbiol Infect Dis 10, 68-70.

Tarnvik, A. (1989). Nature of protective immunity to Francisella tularensis. Rev Infect Dis 11, 440-451.

Tarnvik, A. \& Chu, M. C. (2007). New approaches to diagnosis and therapy of tularemia. Ann N Y Acad Sci 1105, 378-404.

Tarnvik, A., Sandstrom, G. \& Sjostedt, A. (1996). Epidemiological analysis of tularemia in Sweden 1931-1993. FEMS Immunol Med Microbiol 13, 201-204.

Telepnev, M., Golovliov, I., Grundstrom, T., Tarnvik, A. \& Sjostedt, A. (2003). Francisella tularensis inhibits Toll-like receptor-mediated activation of intracellular signalling and secretion of TNF- $\alpha$ and IL1 from murine macrophages. Cell Microbiol 5, 41-51.

Tempel, R., Lai, X. H., Crosa, L., Kozlowicz, B. \& Heffron, F. (2006). Attenuated Francisella novicida transposon mutants protect mice against wild-type challenge. Infect Immun 74, 5095-5105.
Thakran, S., Li, H., Lavine, C. L., Miller, M. A., Bina, J. E., Bina, X. R. \& Re, F. (2007). Identification of Francisella tularensis lipoproteins that stimulate the Toll-like receptor (TLR) 2/TLR1 heterodimer. J Biol Chem 283, 3751-3760.

Thomas, R. M., Titball, R. W., Oyston, P. C. F., Griffin, K., Waters, E., Hitchen, P. G., Michell, S. L., Grice, I. D., Wilson, J. C. \& Prior, J. L. (2007). The immunologically distinct $O$ antigens from Francisella tularensis subspecies tularensis and Francisella novicida are both virulence determinants and protective antigens. Infect Immun 75, 371-378.

Titball, R. W. \& Petrosino, J. F. (2007). Francisella tularensis genomics and proteomics. Ann N Y Acad Sci 1105, 98-121.

Titball, R. W., Sjostedt, A., Pavelka, M. S., Jr \& Nano, F. E. (2007). Biosafety and selectable markers. Francisella tularensis: biology, pathogenicity, epidemiology, and biodefense. Ann N Y Acad Sci 1105, 405-417.

Twine, S., Bystrom, M., Chen, W. X., Forsman, M., Golovliov, I., Johansson, A., Kelly, J., Lindgren, H., Svensson, K. \& other authors (2005). A mutant of Francisella tularensis strain SCHU S4 lacking the ability to express a 58-kilodalton protein is attenuated for virulence and is an effective live vaccine. Infect Immun 73, 8345-8352.

Vinogradov, E., Perry, M. B. \& Conlan, J. W. (2002). Structural analysis of Francisella tularensis lipopolysaccharide. Eur J Biochem 269, 61126118.

Vinogradov, E., Conlan, W., Gunn, J. S. \& Perry, M. B. (2004). Characterisation of the lipopolysaccharide O-antigen of Francisella novicida. Carbohydr Res 339, 649-654.

Wang, X., Ribeiro, A. A., Guan, Z., McGrath, S. C., Cotter, R. J. \& Raetz, C. R. H. (2006). Structure and biosynthesis of free lipid A molecules that replace lipopolysaccharide in Francisella tularensis subsp. novicida. Biochemistry 45, 14427-14440.

Weiss, D. S., Brotcke, A., Henry, T., Margolis, J. J., Chan, K. \& Monack, D. M. (2007). In vivo negative selection screen identifies genes required for Francisella virulence. Proc Natl Acad Sci U S A 104, 6037-6042.

Whipp, M. J., Davis, J. M., Lum, G., de Boer, J., Zhou, Y., Bearden, S. W., Petersen, J. M., Chu, M. C. \& Hogg, G. (2003). Characterization of a novicida-like subspecies of Francisella tularensis isolated in Australia. J Med Microbiol 52, 839-842. 